\title{
ERYTHROCYTIC ANOMALIES IN HEREDITARY VITREO-RETINAL DEGENERATION (DEGENERATIO HYALOIDEORETINALIS)*
}

\author{
BY
}

A. KAHÁN, I. L. KAHÁN, AND A. BENKŐ

WITH THE TECHNICAL ASSISTANCE OF

S. MINDSZENTI

From the Department of Ophthalmology and the First Department of Medicine, University Medical School, Szeged, Hungary

Two hereditary syndromes characterized by the association of retinal changes and erythrocytic anomalies have been described:

(1) Retinopathy complicating haemoglobin anomalies, thalassaemia (Rudd, Evans, and Peeney, 1953), or sickle-cell anaemia (Lieb, Geeraets, and Guerry, 1959);

(2) Atypical retinitis pigmentosa with thorny erythrocytes (acanthocytosis: Bassen and Kornzweig, 1950; Kornzweig and Bassen, 1957; Jampel and Falls, 1958; Mier, Schwartz, and Boshes, 1960; Druez, Lamy, Frézal, Polonovski, and Rey, 1961).

The symptoms of the former, and in particular the appearance of thalassaemic retinopathy (preretinal veils with arcaded edges temporally and chorioretinal atrophy), have some features in common with those of hereditary vitreo-retinal degeneration (Wagner, 1938; Böhringer, Dieterle, and Landolt, 1960). The similarity between the tapeto-retinal degeneration associated with acanthocytosis and the retinal symptoms of vitreo-retinal degeneration is even more remarkable, and some of the biochemical findings of both anomalies suggest their possible role in the pathogenesis of vitreoretinal degeneration.

\section{Criteria of Diagnosis and Method of Examination}

(1) The complete picture of degeneration comprises a triad of symptoms:

(a) An optically "empty" vitreous with a paucity of coarse curly fibres and sometimes glistening white specks. The dense hyaloid membrane interrupted by extensive holes is detached from the retina, veiling it (Figs 1 and 3, opposite), and connected to it by multiple vitreo-retinal adhesions. 


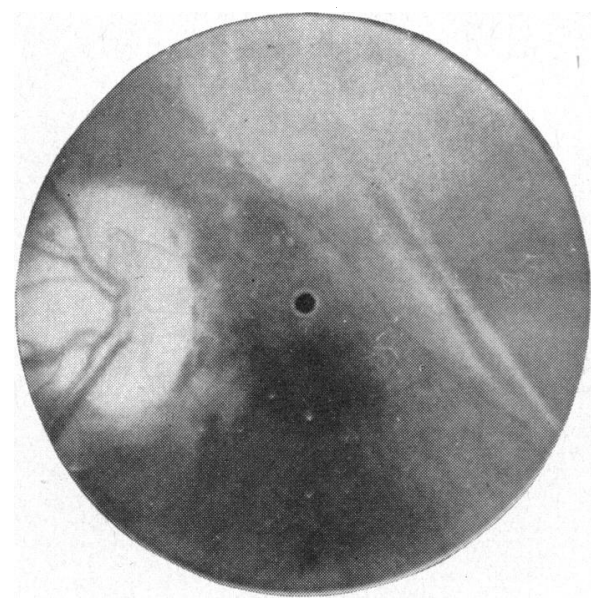

Fig. 1.-Case 1, left eye, translucent folded membrane veiling macula.

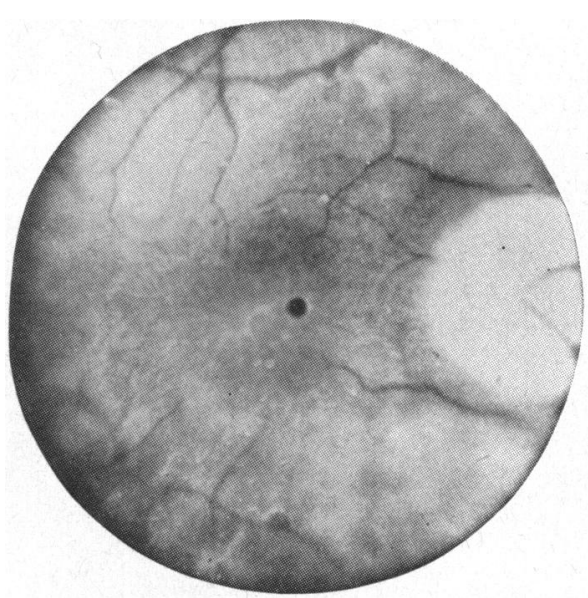

FIG. 2.-Case 2, right eye, cystoid degeneration of macula.

(b) Cystoid degeneration of the macula (Fig. 2) and retinoschisis, most prominent in the lower temporal quadrant, causing central and nasal defects of the visual fields (Figs 4 and 5, overleaf).

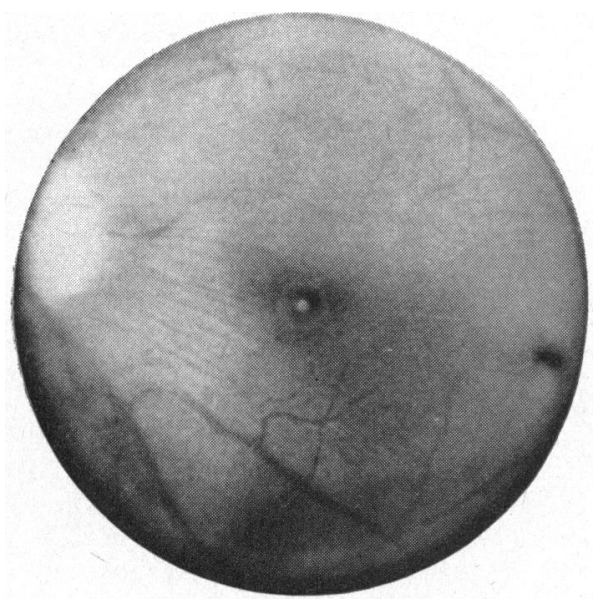

Fig. 3.-Case 4, left eye, horizontal folds of hyaloid membrane in front of macula.

(c) Chorio-retinal atrophy with scattered pigment and a subnormal or extinguished electroretinogram (Figs 6 and 7, overleaf).

Cataract, starting in the posterior cortex at puberty, accompanies the vitreoretinal changes.

Simultaneously with the description given by Wagner (1938), essentially the same picture with the outstanding symptom of vascular veils in the vitreous was described by Mann and Macrae (1938); however, this idiopathic detachment in young men leading to chorio-retinal atrophy (Juler, 1947; Sorsby, Klein, Gann, and Siggins, 1951; Kleinert, 1953; Gieser and Falls, 1961) is a sex-linked anomaly, 

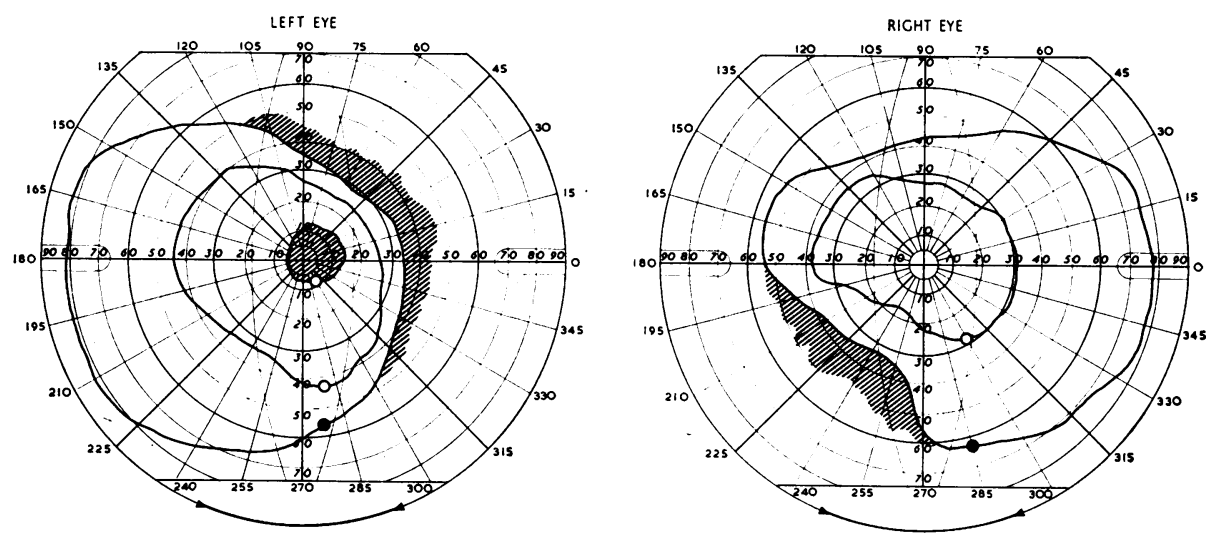

Fig. 4.-Case 1, visual fields, measured by the Goldmann perimeter. $\bullet=64 \mathrm{~mm} .^{2}$ White object $c_{1}=16 \mathrm{~mm} .{ }^{2}$ Blue object
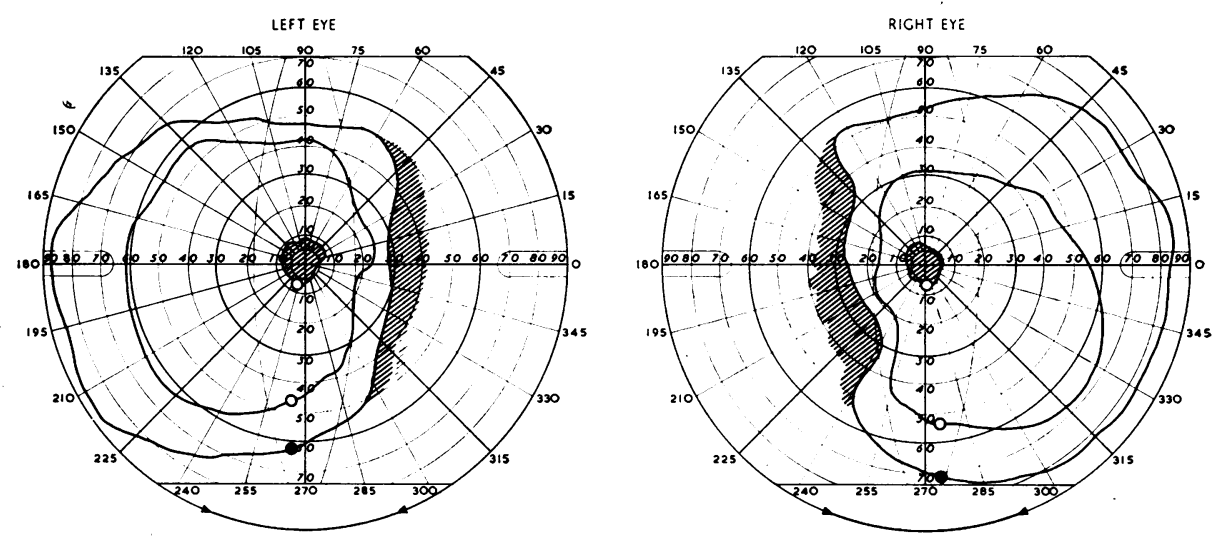

Fig. 5.-Case 2, visual fields, measured by the Goldmann perimeter.

$\bullet=64 \mathrm{~mm} .^{2}$ White object $\quad \bigcirc=16 \mathrm{~mm} .^{2}$ Blue object

while vitreo-retinal degeneration may affect both sexes and is inherited dominantly like the haemoglobin anomalies.

The changes in the vitreous and the cystic degeneration of the retina or retinoschisis were visualized by the contact lens method of Goldmann (1954). The electroretinograms were recorded with the Mingograph (Elema) and by the method of Karpe (1948). Light-thresholds and flicker-fusion frequency were examined with the adaptometer described by Kahán and Oláh (1954).

(2) In contrast to the homozygous form of thalassaemia manifesting itself in severe disease (Cooley's anaemia), the diagnosis of the heterozygous form (thalassaemia minor and minima), which is sometimes suspected on the basis of a mild 


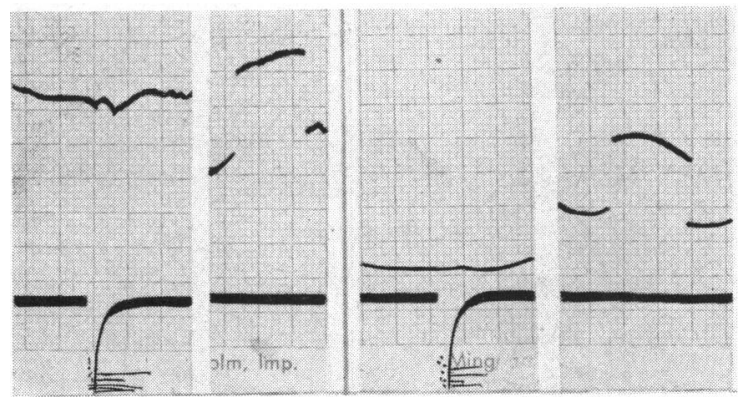

Fig. 6.-Subnormal elec- Fig. 7.-Extinguished electroretinogram in Case 1. troretinogram in Case 2.

hypochromic anaemia and frequent epistaxis (Case 3), is based mainly upon three laboratory findings:

(a) In the natural and Giemsa-stained blood smears, the prevalence of target cells and extremely thin erythrocytes seemingly interrupted by a white ring at the midperiphery (Fig. 8; overleaf). Because of their pronounced biconcave shape, much swelling may occur in hypotonic solutions without rupturing the cells, their osmotic fragility being decreased to below 0.48 to 0.32 per cent. $\mathrm{NaCl}$.

(b) The thalassaemic gene manifests itself by interfering with the formation of normal adult haemoglobin $A_{1}$ or of its $\beta$ chains, and the response is an enhanced synthesis of the other minor haemoglobin components present in normal adult erythrocytes: $\mathrm{Hb} \mathrm{F}$ and $\mathrm{Hb} \mathrm{A}_{2}$ (Jonxis, 1961). Erythrocytes containing $\mathrm{Hb} \mathrm{F}$ may also be seen in blood smears stained by the procedure of Kleihauer and Betke (1960) where, in contrast to normal adult haemoglobin, $\mathrm{Hb} \mathrm{F}$ remains uneluted by the acid citrate-phosphate buffer and is stained red by erythrosin as occurs in a certain proportion of the erythrocytes of infants (Fig. 9, overleaf). $\mathrm{Hb} \mathrm{F}$, when present in quantities greater than in normal adults, may be separated from $\mathrm{Hb} \mathrm{A}_{1}$ and identified by the agar-gel electrophoresis of haemolysates (Fig. 10, overleaf), moving at $\mathrm{pH} 6.2$ faster than the former towards the cathode (Robinson, Robson, Harrison, and Zuelzer, 1957). Quantitative determination of Hb F is more easily performed in that it is a hundred times more alkali resistant than $\mathrm{Hb} \mathbf{A}$. During this study we changed from the original Singer test (Singer, Chernoff, and Singer, 1951) to the method of Kristoffersen (1961), salting out the alkali-denaturated haemoglobin with $45 \cdot 8$ per cent. saturated $\mathrm{NH}_{4}{ }_{2} \mathrm{SO}_{4}$, and measuring the $\mathrm{Hb}$ concentration at $413 \mathrm{~m} \mu$. The former yielded normal values up to 2 per cent. and the latter only up to 0.8 per cent. $\mathrm{Hb} F$, and was therefore considered to be more specific. It should be emphasised, however, that such tests lack specificity in determining all the break-down products of alkali-resistant haemoglobin, and that their diagnostic value is limited since $\mathrm{Hb} \mathrm{F}$ is increased in several cases of chronic hyporegenerative anaemia.

(c) A more specific manifestation of the thalassaemic trait is an increase in the $\mathrm{Hb} \mathrm{A}_{2}$ component above 3.5 per cent. Separation was performed by paper electrophoresis in tris-EDTA-borate and barbital discontinuous buffer systems, 


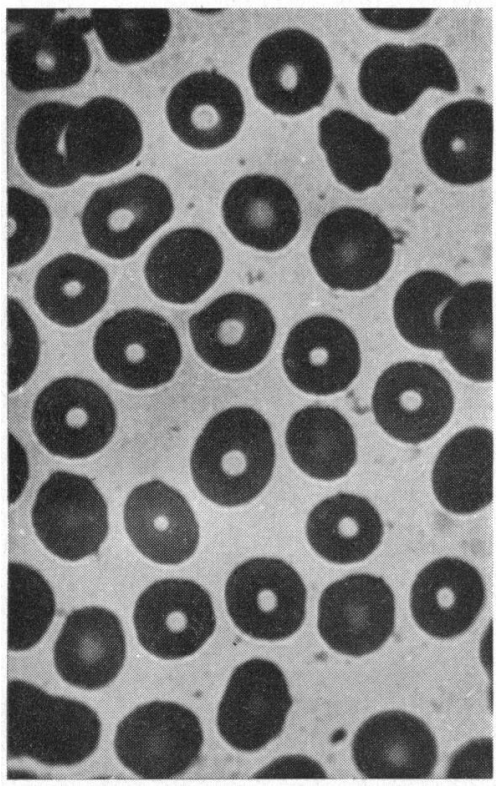

FIG. 8.-Giemsa-stained peripheral blood smears from Case 1 , showing prevalence of target cells. $\times 600$.

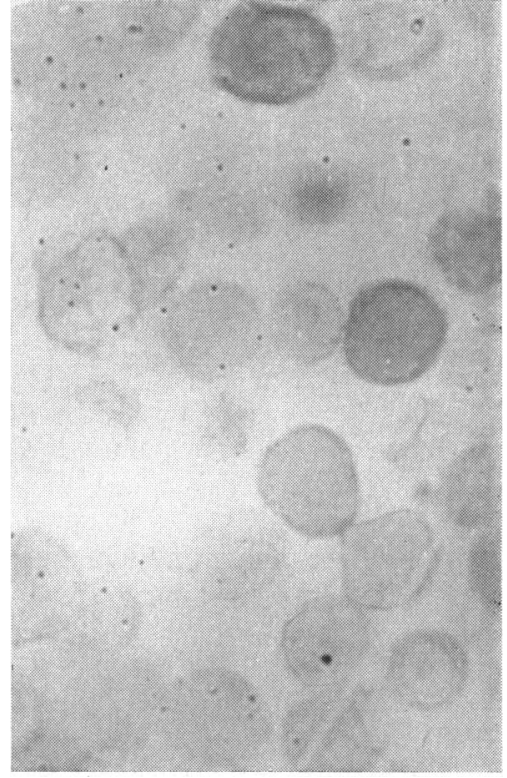

FIG. 9.-Peripheral blood smears stained by the method of Kleihauer and Betke (1960), from a 3-month-old baby, exhibiting several erythrocytes containing $\mathrm{Hb} \mathrm{F} . \quad \times 600$.

as described by Goldberg (1959), and quantitative evaluation was performed by measuring the density of the unstained paper strips. When stained with amidoblack, two non-haemoglobin protein fractions of slower motility than $\mathrm{Hb} \mathrm{\textrm {A } _ { 2 }}$ appeared (Fig. 11). In cases of thalassaemia, high serum $\gamma$-globulin (Aksoy, Alpüstün, Devrimel and Pecel, 1961) and low serum lipid values (Choremis, Kyriakides, and Papadakis, 1961) have been described.

(3) Acanthocytosis is characterized by the prevalence of erythrocytes with several irregularly-spaced thorny protuberances of unequal shape (Fig. 12). They are easily distinguished from the numerous, regularly-spaced, and uniform spikes attributed to the action of hypertonic solutions (Singer, Fisher, and Perlstein, 1952), and are visible not only in natural unstained smears but also in wet preparations of fresh blood diluted with hypotonic saline and sealed with a coverslip and vaseline.

This anomaly is bound to the erythrocytes and not to the plasma, being visible when the patients' washed erythrocytes are suspended in normal serum or Ringer solution, but not if normal erythrocytes are suspended in the serum of the patients.

However, this inborn erythrocytic anomaly is clinically coupled with low fasting total serum lipid values (Cases 2 and 3 ) determined by extraction and weighing, as described by Lindholm (1956), the lower limit of normal being $600 \mathrm{mg}$. per cent., and with low levels of cholesterol determined by the method of Zak, Dickenman, White, Burnett, and Chernay (1954). 


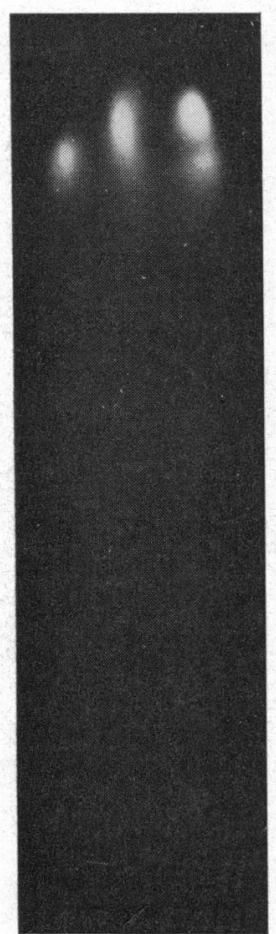

Fig. 10.-Agar-electrophoretic separation of $\mathrm{Hb} \mathrm{F}$ and $\mathrm{Hb} \mathrm{A}$. From left to right:

(a) Haemolysate of a normal adult

(b) Haemolysate of a 3-week-old baby

(c) Haemolysate of Case 1.
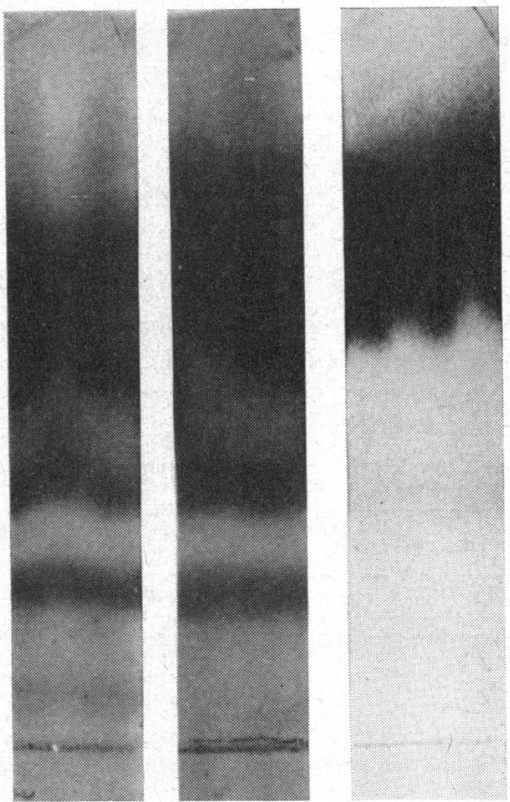

FIG. 11.-Paper electrophoretic separation of $\mathrm{Hb} \mathrm{A}_{2}$ and $\mathrm{Hb} \mathrm{A}_{1}$ in a discontinuous buffer system. From left to right:

(a) Haemolysate of a normal adult

(b) Haemolysate of Case 1. Amidoblack stain

(c) Haemolysate of Case 1. Unstained.

In the last the non-haemoglobin components of the haemolysate remain undetected. 
In our cases of acanthocytosis, the most prominent feature was the reduction of non-esterified (digitonin-precipitable) cholesterol, determined by the method of Zak, Luz, and Fisher (1957), to less than 20 per cent. of total cholesterol. These serum lipid anomalies are considered not to cause but to accompany the erythrocytic anomaly (Jampel and Falls, 1958; Mier and others, 1960; Druez and others, 1961).

\section{Case Reports}

The detailed results of the general and haematological examinations of our four cases are summarized in the Table.

TABLE

RESULTS OF GENERAL EXAMINATION AND LABORATORY DATA

\begin{tabular}{|c|c|c|c|c|}
\hline Case No. & 1 & 2 & 3 & 4 \\
\hline Habitus & Asthenic & Asthenic & Asthenic & Asthenic \\
\hline $\begin{array}{l}\text { Degenerative } \\
\text { Stigmata }\end{array}$ & $\begin{array}{l}\text { Jug-ears } \\
\text { Kyphoscoliosis } \\
\text { Microcornea conus } \\
\text { medialis }\end{array}$ & $\begin{array}{l}\text { Jug-ears } \\
\text { Kyphoscoliosis } \\
\text { Hernia inguinalis } \\
\text { Microcornea conus } \\
\text { medialis }\end{array}$ & $\begin{array}{l}\text { Scapulae alatae } \\
\text { Ptosis of kidneys } \\
\text { Persistent pupillary } \\
\text { membrane }\end{array}$ & $\begin{array}{l}\text { Persistent hyaloid } \\
\text { artery }\end{array}$ \\
\hline $\begin{array}{l}\text { Radiography of Skull, } \\
\text { Knees, and Elbows }\end{array}$ & Normal & Normal & Normal & Normal \\
\hline Fluoroscopy of Chest & Normal & $\begin{array}{l}\text { Calcified } \\
\text { subclavicular foci } \\
\text { and lymph-nodes }\end{array}$ & $\begin{array}{l}\text { Calcified } \\
\text { subclavicular } \\
\text { focus }\end{array}$ & Calcified scars \\
\hline $\begin{array}{l}\text { Mantoux Reaction } \\
(1: 10,000)\end{array}$ & + & Neg. & Neg. & Neg. \\
\hline $\begin{array}{l}\text { Enlarged Liver and } \\
\text { Spleen }\end{array}$ & Absent & Absent & Absent & Absent \\
\hline Enlarged Lymph Nodes & Present on the neck & Present on the neck & None & Present \\
\hline Heart & Systolic murmur & $\begin{array}{l}\text { Aorta II sound } \\
\text { accentuated }\end{array}$ & Normal & Normal \\
\hline $\begin{array}{l}\text { Blood Pressure } \\
\text { (mm. Hg) }\end{array}$ & $130 / 90$ & $150 / 100$ & $115 / 90$ & $115 / 90$ \\
\hline Serum $\left|\begin{array}{l}\text { Total Protein } \\
\text { (g. per cent) } \\
\text { Albumin (g. per cent.) } \\
\alpha_{1} \text {-globulin (g. per cent) } \\
\alpha_{2} \text {-globulin (g. per cent) } \\
\beta-\text { globulin (g. per cent.) } \\
\gamma \text {-globulin (g. per cent.) }\end{array}\right|$ & $\begin{array}{l}8 \cdot 0 \\
3 \cdot 37 \\
0 \cdot 30 \\
1 \cdot 08 \\
1 \cdot 48 \\
1 \cdot 82\end{array}$ & $\begin{array}{l}7 \cdot 8 \\
3 \cdot 1 \\
0 \cdot 33 \\
0 \cdot 94 \\
1 \cdot 38 \\
2 \cdot 03\end{array}$ & $\begin{array}{l}6 \cdot 6 \\
3 \cdot 2 \\
0 \cdot 28 \\
0 \cdot 54 \\
0 \cdot 86 \\
1 \cdot 72\end{array}$ & $\begin{array}{l}7 \cdot 3 \\
4 \cdot 03 \\
0 \cdot 30 \\
0 \cdot 50 \\
0 \cdot 72 \\
1 \cdot 75\end{array}$ \\
\hline $\begin{array}{l}\text { Total Lipids } \\
\text { (mg. per cent.) }\end{array}$ & 462 & 436 & 470 & 842 \\
\hline $\begin{array}{l}\text { Cholesterol } \\
\text { Total (mg. per cent.) } \\
\text { Non-esterified (per } \\
\text { cent of total) }\end{array}$ & $\begin{array}{r}162 \\
25 \\
\end{array}$ & $\begin{array}{r}175 \\
16 \\
\end{array}$ & $\begin{array}{l}225 \\
5 \cdot 9\end{array}$ & $\begin{array}{r}180 \\
7 \\
\end{array}$ \\
\hline $\begin{array}{l}\text { Phospholipids } \\
\text { (mg. per cent.) }\end{array}$ & 165 & 150 & 145 & 212 \\
\hline Iron ( $\mu g$. per cent.) & 94 & 112 & 44 & 62 \\
\hline Bilirubin (mg. per cent.) & 0.68 indirect & 0.58 indirect & 0.36 indirect & 0.98 indirect \\
\hline $\begin{array}{l}\text { Erythrocyte } \\
\text { Sedimentation, Rate } \\
\text { (mm./1 hr) } \\
\text { R.B.C. (106/cu. mm.) }\end{array}$ & $\begin{array}{r}8 \\
4 \cdot 6\end{array}$ & $\begin{array}{r}2 \\
4 \cdot 2\end{array}$ & $\begin{array}{l}14 \\
3 \cdot 6\end{array}$ & $\begin{array}{r}7 \\
4 \cdot 1\end{array}$ \\
\hline $\begin{array}{c}\text { Reticulocytes } \\
\text { (per thou.) }\end{array}$ & $4 \cdot 2$ & $2 \cdot 5$ & 7 & 16 \\
\hline
\end{tabular}


TABLE-continued

\begin{tabular}{|c|c|c|c|c|c|c|}
\hline \multicolumn{3}{|c|}{ Case No. } & 1 & 2 & 3 & 4 \\
\hline \multicolumn{3}{|c|}{$\begin{array}{l}\text { Haemoglobin } \\
\text { (g. per cent.) }\end{array}$} & $14 \cdot 2$ & $15 \cdot 3$ & $10 \cdot 8$ & $11 \cdot 6$ \\
\hline \multicolumn{3}{|c|}{$\begin{array}{l}\text { W.B.C. (10 } 3 / \text { cu. mm.) } \\
\text { Band Form, per cent. } \\
\text { Neutrophils, per cent. } \\
\text { Hypersegmented } \\
\text { (per cent.) } \\
\text { Eosinophils, per cent. } \\
\text { Basophils, per cent. } \\
\text { Lymphocytes, per cent. } \\
\text { Monocytes, per cent. }\end{array}$} & $\begin{array}{lr} & 7 \cdot 4 \\
\text { None } & 67 \\
\text { None } & \\
& 2 \\
\text { None } & 30 \\
& 1\end{array}$ & $\begin{array}{lr} & \begin{array}{r}6 \cdot 8 \\
3\end{array} \\
& 62 \\
\text { None } & \\
& 3 \\
\text { None } & 32 \\
\text { None } & \end{array}$ & $\begin{array}{r}7 \cdot 8 \\
1 \\
53 \\
1 \\
\\
42 \\
3\end{array}$ & $\begin{array}{r}9 \cdot 2 \\
5 \\
68 \\
4 \\
3 \\
18 \\
2\end{array}$ \\
\hline \multicolumn{3}{|c|}{ Platelets (105/cu. mm.) } & & & $4 \cdot 03$ & $3 \cdot 5$ \\
\hline \multicolumn{3}{|c|}{$\begin{array}{l}\text { Osmotic Fragility } \\
\text { per cent. } \mathrm{NaCl}\end{array}$} & $0.42-0.22$ & $0.42-0.22$ & $0.46-0.22$ & $0.40-0.22$ \\
\hline \multicolumn{3}{|c|}{ Target Cells } & Prevalent & Some & Some & Prevalent \\
\hline \multicolumn{3}{|c|}{ Acanthocytes } & Some & Prevalent & Prevalent & None \\
\hline \multirow{4}{*}{$\mathbf{H b}$} & \multicolumn{2}{|c|}{$\begin{array}{c}\text { F containing } \\
\text { erythrocytes }\end{array}$} & Present & Present & Present & None \\
\hline & \multicolumn{2}{|c|}{$\begin{array}{l}\text { F per cent. } \\
\text { Singer method } \\
\text { Kristoffersen } \\
\text { method }\end{array}$} & 8 & $\begin{array}{l}3 \\
1 \cdot 56\end{array}$ & $\begin{array}{l}1 \\
1 \cdot 78\end{array}$ & $1 \cdot 25$ \\
\hline & \multicolumn{2}{|c|}{$\begin{array}{l}\text { F separation by } \\
\text { agar-gel electro- } \\
\text { phoresis }\end{array}$} & Well separated & Neg. & Neg. & Neg. \\
\hline & \multicolumn{2}{|c|}{$\mathbf{A}_{2}$ per cent. } & $3 \cdot 8$ & $2 \cdot 5$ & $2 \cdot 8$ & 4 \\
\hline \multicolumn{3}{|c|}{ Bone Marrow Puncture } & $\begin{array}{l}\text { Normal erythro- } \\
\text { poiesis eosino- } \\
\text { philia }\end{array}$ & $\begin{array}{l}\text { Normal erythro- } \\
\text { poiesis } \\
\text { Slightly increased } \\
\text { number of plasma } \\
\text { cells } \\
\text { Eosinophilia }\end{array}$ & $\begin{array}{l}\text { Normal erythro- } \\
\text { poiesis and } \\
\text { granulopoietis } \\
\text { Slightly increased } \\
\text { megakaryocytes } \\
\text { and plasma cells }\end{array}$ & $\begin{array}{l}\text { Succeeded at third } \\
\text { attempt after } \\
\text { successful therapy } \\
\text { of retrovitreal } \\
\text { haemorrhages } \\
\text { Prevalence of } \\
\text { megakaryocytes }\end{array}$ \\
\hline \multirow{2}{*}{\multicolumn{2}{|c|}{$\begin{array}{l}\text { Urine } \\
\text { (mg./24 hrs) }\end{array}$}} & Urobilin & $0 \cdot 27$ & 0.9 & & \\
\hline & & Stercobilin & 0.03 & 0.01 & & \\
\hline
\end{tabular}

Cases 1 and 2 were male twins aged 13 years, who presented themselves at an interval of 105 days with strikingly similar histories and the typical clinical appearance of haemoglobin anomalies.

Case 1. After gymnastic exercises, this boy became aware of a sudden blurring of vision in the left eye.

\section{Examination}

Visual acuity in the right eye $5 / 15$, with $-7 \mathrm{D}$ sph., $-2 \mathrm{D}$ cyl., axis $170^{\circ}$, and in the left eye $5 / 40$, with $-6 \mathrm{D}$ sph., $-2 \mathrm{D}$ cyl., axis $170^{\circ}$.

Corneal diameter $10 \mathrm{~mm}$.

The right vitreous was optically "empty"; the detached hyaloid membrane was particularly opaque on the temporal side near the ora serrata like a twisted ribbon; the disc was pale, the macula honeycomb-like, the periphery speckled with superficial pigment, the temporal periphery of the retina prominent $(8 \mathrm{D})$.

In the left vitreous roughly scattered blood obscured the temporal part of the fundus. One month later, when the haemorrhages cleared, a picture similar to that of the right eye became visible.

During 3 years of observation, the corrected visual acuity of both eyes remained essentially unchanged with slight field defects in the nasal superior quadrants, and a blue 
central scotoma in the left eye (Fig. 4). The latter was already divergent vertically, with occasional slight vertical nystagmus. The disc was pale, and a dense fold of translucent membrane veiled the left macula (Fig. 1) and merged in the temporal periphery with the opaque surface of the prominent swollen retina, which was interrupted by a round hole and ended with a peripheral detachment.

In the posterior cortex of both lenses fine opacities developed.

The electroretinogram was almost extinguished (Fig. 6).

There was moderate hemeralopia, both the rod and cone thresholds being $0.6 \mu \mu$ Lamberts above normal. The frequency of flicker fusion was 11 per sec.

Laboratory Findings. - Prevalence of target cells (Fig. 8), decreased osmotic fragility of red blood cells, $\mathrm{Hb} \mathrm{F}$ - containing erythrocytes, increase and agar-electrophoretic separation of $\mathrm{Hb} \mathrm{F}$ (Fig. 10), and slightly increased $\mathrm{Hb} \mathrm{A}_{2}$ (Fig. 11) favoured the diagnosis of thalassaemia minor.

Case 2. After underwater swimming, this boy saw a red mass progressively obscuring the sight of the left eye.

\section{Examination:-}

Visual acuity in the right eye $5 / 7$, with $-3.5 \mathrm{D} \mathrm{sph}$., and in the left eye hand movements. Corneal diameter $10.5 \mathrm{~mm}$.

The vitreous of the right eye seemed structureless, its detached hyaloid membrane was opaque on the temporal side, forming a twisted ribbonlike opacity interrupted by holes. The disc was pale. Cystoid degeneration of the macula was most striking in this case (Fig. 2). Temporally the retina exhibited pigment-mottling and a convex surface.

In the left eye, the red reflex was abolished by massive intravitreal haemorrhages, which dispersed after 2 months, when visual acuity improved to $5 / 10$, with $-2.5 \mathrm{D}$ sph., $-2 \mathrm{D}$ cyl., axis $160^{\circ}$.

The disc was pale with cystoid degeneration of the posterior pole and preretinal vascular veils with extensive holes in the temporo-inferior quadrant.

After 3 years' a slow progression of the process was observed. The corrected visual acuity was 5/12, with central blue scotomata, and nasal field defects (Fig. 5).

The electroretinogram was completely abolished (Fig. 7).

The rod and cone thresholds and frequency of flicker fusion were exactly like that of Case 1.

Laboratory Findings.-Prevalence of acanthocytes (Fig. 12), decreased osmotic fragility of erythrocytes, few $\mathrm{Hb}$ F-containing erythrocytes, raised serum $\mathrm{Hb} \mathrm{F}$ level, low total serum lipid and free cholesterol levels.

Hereditary data for these two cases are scanty. The blood smear of the boys' father contained numerous target cells and acanthocytes, but no abnormal signs. The mother showed no anomalies. The boys were their only children.

Case 3, a girl aged 20 years, complained of black spots disturbing the vision of the right eye and frequent epistaxis. Both symptoms were alleviated by massive doses of ascorbic acid.

Examination.-The visual acuity of both eyes was 5/5. Remnants of pupillary membrane were seen on both lens capsules with dustlike remnants of haemorrhages, and detachment of the hyaloid membrane of both vitreous bodies.

In the right eye, the detached hyaloid membrane was dense infero-nasally, sparsely vascularized, and interrupted by numerous extensive holes. One hole at 4 o'clock was accentuated by a torn-off operculum of the same colour and twisted appearance as in Cases 1 and 2 . In the periphery, the membrane ended with arcaded edges like disinsertions. The disc was poorly vascularized, there was no foveolar reflex, and the perifoveal reflex was silky with peripheral pigment mottling. 
Behind the left lens, three glistening white specks attached to vitreous fibres were seen. In the temporal periphery there were vascular veils. There was a blue field defect in the upper temporal quadrant of the right eye. The electroretinogram showed a pronounced a-wave and negative afterswing (Fig. 13).

The light thresholds and flicker fusion frequency were normal.

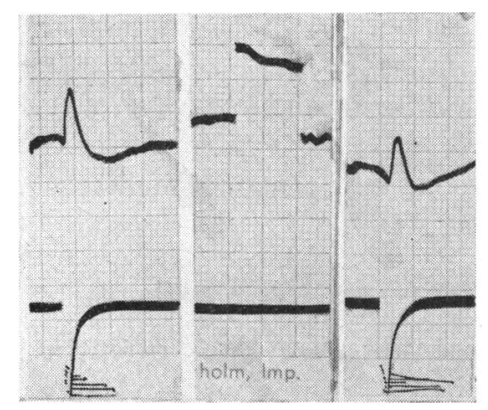

FIG. 13.-Accentuated a-wave in Cases 3 and 4 , and negative afterswing in Case 3.

Laboratory Findings.-Anaemia with predominant acanthocytosis, some target cells, decreased osmotic fragility of red blood cells, Hb F-containing erythrocytes, slightly raised serum $\mathrm{Hb} F$ levels (insufficient to be shown by agar-gel electrophoresis), and normal $\mathrm{Hb} \mathrm{\textrm {A } _ { 2 }}$ levels. The most prominent feature besides the acanthocytosis was the low level of total serum lipids, particularly that of non-esterified cholesterol.

No data were available concerning other members of the family.

Case 4, a girl aged 9 years, had the vision of the left eye suddenly blurred by red clouds and was then seen again 7 years later with essentially the same history.

Examination (at the age of 9 years). - The visual acuity in the right eye was 5/50 with $-8 \mathrm{D}$ sph., and in the left eye 5/15 (emmetropic).

The most prominent symptom was the detachment of the hyaloid membrane of the left eye, particularly opaque in the neighbourhood of the disc, adherent to its superior margin, and horizontally folded in front of the macula. The retrovitreal space was laden with a cloud of finely distributed haemorrhages.

On a presumptive diagnosis of Eales's disease of tubercular origin, PAS and INH were administered, but with no effect. Chest fluoroscopy and the Mantoux test $(1: 10,000)$ were found to be negative, but moderate anaemia was present (red blood cells $3 \cdot 800,000$; $\mathrm{Hb} 11 \cdot 3$ g. per cent.).

The vision of the left eye was restored to $5 / 5$ after large doses of ascorbic acid.

The child was then free of complaints until she was admitted again at the age of 16 years.

Examination.-The visual acuity of the right eye was 5/50, with -10 D sph., and in the left eye $5 / 20$ (emmetropic).

The right vitreous was found optically "empty", with a posteriorly detached hyaloid membrane. The surface of the retina appeared prominent in the temporal periphery (26 D).

In the left eye, detachment and collapse of the vitreous with retrovitreal haemorrhages were evident; these resorbed after 2 weeks rest in bed and the administration of ascorbic acid, permitting full evaluation and photography of the fundus changes. The scarred 
and vascularized hyaloid membrane was detached in the vicinity of the disc, fused with a remnant of the hyaloid artery, and stretched in horizontal folds in front of the macula (Fig. 3), veiling the temporal midperiphery but adherent to a temporal retinoschisis. In the lower-temporal quadrant, the hyaloid membrane was interrupted by multiple holes with ribbon-like glistening margins.

The visual acuity in the left eye was now 5/5. There was a blue field defect in the upper nasal quadrant. The electroretinogram showed a pronounced a-wave $(100 \mu \mathrm{V})$ and negative afterswing. The b-wave was $250 \mu \mathrm{V}$ (Fig. 13).

Laboratory Findings.-Moderate anaemia with slightly raised reticulocyte count, prevalence of target cells, decreased osmotic fragility of erythrocytes, and $\mathrm{Hb}_{\mathbf{2}}$ slightly above the normal range.

The patient's mother's blood smear contained numerous target cells but she showed no ocular anomalies.

\section{Discussion}

All four patients presented with signs of intravitreal and/or retrovitreal haemorrhage, and a history reminiscent of Eales's disease. However, the finding of symmetrical changes in the hyaloid membrane and retinoschisis early in the second decade of life at the same time as the first haemorrhage in one eye and ocular and extra-ocular congenital malformations in the fellow eye suggest that these changes are the cause rather than the result of the retrovitreal haemorrhages. The primary changes involve the hyaloid membrane, the internal limiting membrane of the retina, and retinal cellular elements (bipolars and photoreceptors). The resultant retinoschisis in the lower temporal quadrant and the extinguished electroretinogram favour a diagnosis of vitreo-retinal degeneration rather than of retinal periphlebitis.

The full picture of the changes characteristic of vitreo-retinal degeneration was accompanied in Case 1 by symptoms of thalassaemia minor and in Case 2 by those of acanthocytosis. As Case 2 is the twin of Case 1 and of the same sex, he is probably also a carrier of the thalassaemia trait.

The less complete ocular picture in Case 3 is associated with definite acanthocytosis, and the abnormal laboratory findings (e.g., $\mathrm{Hb} \mathrm{\textrm {A } _ { 2 }}$ above the normal range) in Case 4 suggest the presence of thalassaemia minima.

This association of thalassaemia and acanthocytosis with erythrocytic anomalies and vitreo-retinal degeneration is seemingly not a mere coincidence. In contrast to the decreased osmotic fragility, both the erythrocytic anomalies are characterized by an increased mechanical surface-fragility in vitro (Singer and others, 1952) or by an augmented haemolysis in vivo associated with a lack of certain lipoproteins.

\section{Summary}

Four cases of hereditary vitreo-retinal degeneration (Wagner, 1938), accompanied by erythrocytic anomalies (acanthocytosis and/or thalassaemia) are recorded; the pathogenic significance of the anomalies observed in the serum lipids is stressed. 


\section{REFERENCES}

Aksoy, M., Alpüstün, H., Devrimel, H., and Peçel, N. (1961). Acta haemat. (Basel), $25,200$.

BASSEN, F. A., and KornzWeIG, A. L. (1950). Blood, 5, 381.

BÖHRINGer, H. R., Dieterle, P., and LANDOlt, E. (1960). Ophthalmologica (Basel), 139, 330.

Choremis, C., Kyriakides, V., and Papadakis, E. (1961). J. clin. Path., 14, 361.

Druez, G., Lamy, M., Frézal, I., Polonovski, I., and Rey, J. (1961). Presse méd., 69, 1546.

Gieser, E. P., and Falls, H. F. (1961). Amer.J. Ophthal., 51, 1193.

Goldberg, C. A. J. (1959). Clin. Chem., 5, 446.

GoldmanN, H. (1954). "Zwei Vorlesungen über Biomikroskopie des Auges". Haag-Streit, Bern.

JAMPEL, R. S., and FAlls, H. F. (1958). A.M.A. Arch. Ophthal., 59, 818.

JoNXIS, J. H. P. (1961). J. Pediat., 59, 765.

JULER, F. (1947). Trans. ophthal. Soc. U.K., 67, 83.

KAHÁN, A., and OLÁH, I. (1954). Acta med. hung., 5, 175.

KARPE, G. (1948). Docum. ophthal., 2, 268.

KLEIHAUER, E., and BETKE, K. (1960). Internist, 1, 292.

KleINERT, H. (1953). v. Graefes Arch. Ophthal., 154, 295.

Kornzweig, A. L., and Bassen, F. A. (1957). A.M.A. Arch. Ophthal., 58, 183.

KRISTOFFERSEN, K. (1961). Scand. J. clin. Lab. Invest., 13, 402.

LIEB, W. A., GeERAETS, W. J., and GUERRY, D. (1959). Acta ophthal. (Kbh.), Suppl. 58.

LINDHOLM, H. (1956). Scand. J. clin. Lab. Invest., 8, Suppl. 23, p. 25.

ManN, I., and MaCRAe, A. (1938). Brit. J. Ophthal., 22, 1.

Mier, M., Schwartz, S. O., and Boshes, B. (1960). Blood, 16, 1586.

Robinson, A. R., Robson, M., Harrison, A. P., and Zuelzer, W. W. (1957). J. Lab. clin. Med., 50, 745.

Rudd, C., Evans, P. J., and Peeney, A. L. P. (1953). Brit. J. Ophthal., 37, 353.

Singer, K., Chernoff, A. I., and Singer, L. (1951). Blood, 6, 413. Fisher, B., and Perlstein, M. A. (1952). Ibid., 7, 577.

Sorsby, A., KleIN, M., GANN, J. H., and Siggins, G. (1951). Brit. J. Ophthal., 35, 1.

WAGNER, H. (1938). Klin. Mbl. Augenheilk., 100, 840.

ZaK, B., Dickenman, R. C., White, E. G., Burnett, H., and Chernay, P. J. (1954). Amer. J. clin. Path., 24, 1307. , Luz, D. A., and Fisher, M. (1957). Amer. J. med. Technol., 23, 283. 